\title{
PELATIHAN PEMANFAATAN GOOGLE CLASSROOM SEBAGAI MEDIA PEMBELAJARAN DITENGAH PANDEMI COVID-19 BAGI GURU SMPN 1 AIKMEL
}

Muhamad Masjun Efendi ${ }^{1}$, Muhammad Yunus ${ }^{2}$

${ }^{1}$ Sistem Informasi, Fakultas Teknologi Informasi dan Komunikasi, Universitas Teknologi Mataram, Jln. Kampus Universitas Teknologi Mataram Kekalik, Mataram, Nusa Tenggara Barat, Indonesia - 83116

${ }^{2}$ Komputerisasi Akuntansi, Fakultas Vokasi, Universitas Teknologi Mataram, Jln. Kampus Universitas Teknologi Mataram Kekalik, Mataram, Nusa Tenggara Barat, Indonesia - 83116

*Penulis koresponden: creativepio@gmail.com

\section{Info Artikel}

\section{Riwayat :}

Dikirim 1 Desember 2021

Direvisi 10 Januari 2022

Diterima 11 Januari 2022

\section{Kata Kunci :}

Google classroom

Online

LMS

\begin{abstract}
Abstrak
Proses belajar pada saat ini dilakukan secara online sejak pandemi. Pada saat ini pembelajaran online dilakukan dengan menggunakan media whatsapp, akan tetapi penggunaan media whatsap ini guru dan siswa mengalami kendala dalam proses belajar misalnya dalam mengkelompokan mata pelajaran dan file yang dikirim guru tidak bisa terstruktur sehingga siswa menjadi bingung, selain itu guru dan siswa kesusahan dalam memberikan dan memngerjakan tugas karena tidak terstrukturnya berkas. Google classroom merupakan salah satu LMS yang sederhana, tapi banyak guru yang masih kesulitan dalam menggunakan google classroom oleh karena itu Tim pengebadian dari Univeristas Teknologi Mataram mencoba untuk memberikan solusi kepada pihak sekolah untuk memberika pelatihan terkait penggunaan google classroom. Kegiatan PkM ini bertujuan untuk meningkatkan keterampilan guru dalam memanfaatkan google classroom. Peserta yang memgikuti kegatan ini adalah guru SMPN 1 Aikmel. Kegiatan ini nantinya bisa bermanfaat bagi guru dan sekolah, dimana guru bisa lebih memahami penggunaan google classroom dan untuk sekolah bisa menjadi media dalam pembelajaran yang dilakukan secara online.
\end{abstract}

\section{PENDAHULUAN}

Pandemi Covid 19 yang masuk ke Indonesia telah memporak porandakan setiap sendi dalam kehidupan. Covid 19 memaksa pemerintah untuk membuat peraturan bekerja dari rumah dan sekolah dari rumah. Dari waktu kewaktu terus terjadi peningkatan pasien hal ini tidak hanya mempengaruhi sistem ekonomi di Indoesia, akan tetapi berpengaruh secara global di semua sektor kehidupan manusia. Tak terkecuali di ranah pendidikan. Berdasarkan Surat Edaran Nomor 4 Tahun 2020 tentang Pelaksanaan Kebijakan Pendidikan dalam masa darurat penyebaran virus, Mendikbud menghimbau agar semua lembaga pendidikan tidak melakukan proses belajar mengajar secara langsung atau tatap muka, melainkan system pembelajaran jarak jauh. Agar proses pembelajaran terus berlangsung maka guru-guru diminta untuk mengajar dengan system online atau yang sering disebut dengan pembelajaran (daring). Awal pandemi pembelajaran dilakukan dengan menggunakan aplikasi whatsapp. Guru memberikan tugas dan menerima hasil belajar siswa dari whatsapp.

Apa yang terjadi dengan penggunaan whatsapp bagi sekolah. Sisitem adminstrasi sekolah menjadi kurang baik. Pihak sekolah hanya menerima laporan hasil bejar siswa, sementara tidak dapat memantau keatifan siswa di dalam kelas. Akhir dinas pendidikan meminta pihak sekolah untuk melakukan pembelajaran dengan menggunaka LMS. Tujuannya agar dapat lebih mudah memantau seluruh aktivitas belajar mengajar. Bagi sekolah yang sudah memiliki web sekolah dan memiliki 
operator dalam pengelolaan web, LMS merupakan hal yang biasa. Namun tidak bagi sekolah yang tidak memiliki web atau memiliki web namun tidak memiliki sumber daya manusia yang mumpuni dalam pengelolaan web.

Banyak aplikasi yang dapat digunakan dalam pembuatan LMS sederhana di tingkat sekolah, salah satunya adalah penggunaan aplikasi Google Apps For Education (GAFE). Google Apps For Education merupakan alat yang digunakan untuk menunjang aktivitas dalam kegaiatan belajar mengajar yang dapat memadukan aplikasi Gmail, Google Drive dan Google Classroom yang dirancang khusus untuk kegiatan belajar disekolah. Pada dasarnya mudah menggunakan aplikasi tersebut, namun karena guruguru di Nusa Tenggara Barat belum terbiasa maka penggunaannya terkesan sulit. Sehingga perlu dilakukan pelatihan adagr guru mampu mengguanakan pembelajaran daring dengan cara singkronus dan asingkronus. Proses belajar mengajar dalam jaringan adalah system belajar yang memberdayakan iptek, pada system ini siswa diajak untuk berinteraksi dalam jaringan seperti internet semua Langkah pembelajaran dilakukan baik individu maupun kelompok dilakukan dengan learning managemen system yang ada disekolahnya. Satu diantara tujuan pembelajaran dalam jaringan adalah untuk memaksimalkan memaksimalkan pembelajaran dimana saja dan kapan saja serta melatih siswa menjadi pebelajar yang mampu menarik kesimpulan atau membuat suatu keputusan. Menurut para ahli pembelajaran dengan daring dapat memaksimalkan siswa untuk belajarm sebab mereka dapat mengulang pembelajaran dengan membuka system LMS yang ada pada sekolah mereka. Sehingga dapat meningkatkan efektivitas pembelajaran peserta didik. Siswa dapat dengan mudah melakukan diskusi yang berfokus pada topik pembelajaran seperti kelas tradisional.

Kegiatan ini merupakan wujud dari salah satu Tridharma Perguruan Tinggi, yaitu pengabdian kepada masyarakat. Pelatihan ini dilakukan guna untuk memberikan manfaat bagi masyarakat agarm khusunya bagi SMPN 1 Aikmel guna tercapai nya prose pembelajaran yang baik dan serta prose belajar mengajar jadi lancar. Selain itu kegiatan ini merupaka perwujudaan dari salah satu misi Universitas Teknologi Mataram yaitu menyelenggarakan pendidikan, penelitian dan pengabdian kepada masyarakat serta kerjasama dengan berbagai instansi dalam dan luar negeri.

\section{METODE PELAKSANAAN}

Kegiatan pengabdian masyarakat ini dilakukan pada bulan Juli sampai dengan Desember 2021. Pada bualan Juli setelah proposal pengabdian masyarakat lulus pendanaan maka tim melakukan konsolidasi dengan pihak sekolah. Hal ini dilakukan untuk menyapakati waktu kegiatan workshop. Kegiatan workshop dilakukan sebanyak 3 kali, tim akan datang satu kali seminggu untuk melakukan pendampingan dan pembimbingan. Pada saat tim datang kesekolah, tim akan memberikan workshop mengenai materi google classroom, satu minggu kedepannya peserta diminta untuk mengerjakan tugas.

Kegiatan Pengabdian kepada Masyarakat di SMP Negeri 1 Aikmel dilakukan melalui beberapa tahapan, antara lain:

\section{a. Persiapan PkM}

Pada tahapan persiapan, pengabdi melakukan analisis situasi mitra di SMPN 1 Aikmel. Tim Pengabdi melakukan wawancara dengan kepala sekolah dan guru. Setelah mendapatkan hasil analisis situasi mitra, tim pengabdian menentukan tujuan dari pengabdian, merencanakan, mengidentifikasi, dan mendesain solusi terhadap permasalahan mitra. Pada tahapan ini, pengabdi menyiapkan materi pelatihan, dan merancang evaluasi pelatihan. Selanjutnya, pengabdi dan mitra menentukan tanggal dan teknis pelaksanaan kegiatan.

b. Pelaksanaan

Setelah seluruh tahapan persiapan selesai dilaksanakan, tahapan selanjutnya adalah pelaksanaan kegiatan yang dilakukan di SMPN 1 Aikmel selama 3 kali. Kegiatan Pengabdian kepada Masyarakat dilaksanakan di Rauang Aula Sekolah dengan diikuti oleh 24 guru SMPN 1 Aikmel.

c. Evaluasi

Tujuan dari Evaluasi ini adalah untuk mengetahui sejauh mana pengetahuan para guru yang mengikuti pelatihan ini dalam menggunakan google classroom.

\section{HASIL DAN PEMBAHASAN}

Guru-guru di SMPN 1 Aikmel merasakan kendala dalam pengelolaan kelas yang berbasis daring. Sistem aplikasi pembelajaran yang biasa mereka gunakan dinilai kurang 
mampu memfasilitasi guru dalam mengelola kelas selama masa Covid 19 khususnya ketika akan diadakanujian. Kendala lain yang dihadapi yaitu kurangnya interaksi yang dapat mereka lakukan dengan siswanya selama pembelajaran online. Guru juga merasa kurang dapat memantau perkembangan siswa secara lebih komprehensif karena tidak dapat mendampingi siswa secara individual. Sebagai tindak lanjut dari analisa data berdasarkan wawancara dengan mitra dan didukung dengan pengamatan langsung di lokasi, maka solusi yang ditawarkan melalui kegiatan ini yaitu pelaksanaan pelatihan learning management system berbasis google classroom untuk guru-guru SMP Negeri 1 Aikmel. Hal ini tentunya mendukung hasil belajar dan mampu melatih kreativitas guru.

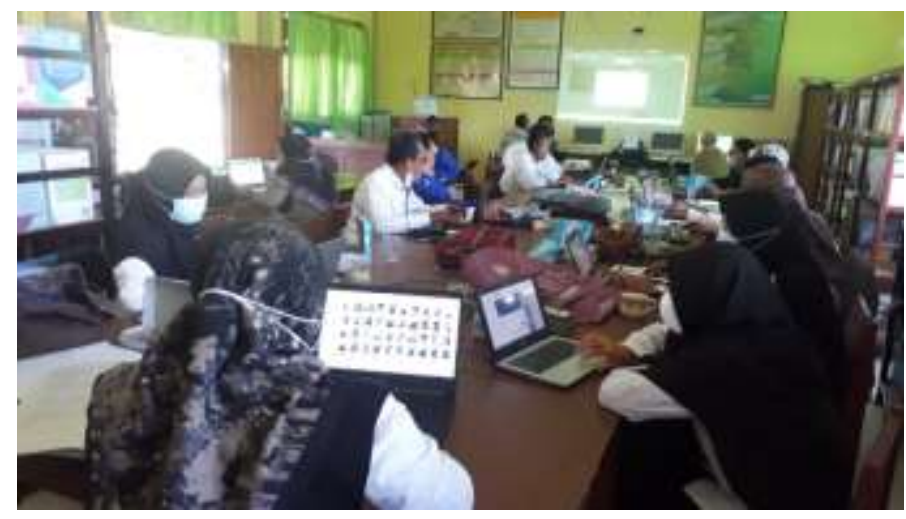

Gambar 1. Suasana kegiatan pelatihan

Kunjungan pertama tim dilakukan pada tanggal 10 Juli 2021 memberikan workshop dengan materi pengenalan google applikasi for education dimulai pukul 8.30 wita sampai dengan pukul 11.00 wita. Bertempat di Ruang Aula SMPN 1 Aikmel yang diikuti oleh 24 (duapuluh empat) orang peserta. Kegiatan workshop dimulai dengan mengenalkan email berupa email gmail yang berfungsi sebagai dasar pada kegiatan pembukaan LMS. Email ini akan berguna untuk membuka kelas pada google classroom, membuat google form dan banyak menu lainnya. Tim memberikan materi. Selain memberikan materi, tim juga memberikan modul untuk jadi bahan pembelajaran dirumah. Pendampingan workshop dilakukan menyebar ke peserta. Pada saat pembuatan email gmail banyak guru yang sudah memiliki akun ini, namun kurang paham penggunaannya bahkan mereka lupa password dan user id. Mereka memiliki akun gmail sebab mereka berinteraksi dengan social media seperti facebook, whatsapp dan intagram.

Setelah kegiatan pelaksanaan workshop pada tahap satu maka peserta diminta untuk membuat email. Instrutur akan memberikan instruksi agar peserta membuat email, lalu memngirimkan email mereka ke instruktur dengan cara mengirimka surat elektronik. Dari suarat elektronik yang diterima maka akan menjadi bahan evaluasi bagi kami untuk langkah kearah selanjutnya. Dari 24 peserta yang ikut pada kegiatan workshop terlihat semua peserta dapat membuat emailnya. Instruktur melanjutkan materi dengan memberikan materi pengenalan google drive.

Untuk kegiatan lanjutan mengenai materi google drive intruktur memberikan penugasan mandiri dikerjakan sebagai tugas rumah. Tugas ini akan dimonitor instruktur melalui pengiriman email peserta kepada instruktur. Dari 24 orang yang menjadi peserta, yang mengirimkan tugas hanya sekitar 12 orang saja. Hal ini menjadi catatan bagi tim bahwa tidak banyak peserta yang bersedia mengerjakan tugas rumah dalam kegiatan ini. Dikarenakan banyak tugas lain yang harus dikerjakan guru-guru seperti kegiatan belajar mengajar. Kendala seperti ini menjadi masukan kepada tim untuk meriview kegiatan workshop. Hasil riviewnya adalah pada pertemuan selanjutnya peserta diminta untuk menyelesaikan semua langkah kegiatan disekolah, tim juga meminta peserta membawa bahan ajar yang akan dipergunakan untuk kegiatan pembelajaran yang sesuangguhnya.

Pada tanggal 17 Juli diadakan kegiatan worshop kedua dengan memberikan materi membuat kuis dan tugas melalui google form serta melakukan tatap muka dengan google meet. Intruktur memberikan pengarahan bagaimana membuat quis yang dapat diacak jawaban dan soalnya. Peserta sangat antusias mendengarkan pengarahan dariinstruktur. Menurut peserta mereka baru kali ini dapat ilmu mengenai bagaimana merancang evaluasi secara online. Materi yang disampaikan instruktur 
dicoba dikerjakan peserta pada saat workshop hasilnya 20 peserta mampu membuat aplikasi evaluasi sederhana. Membuat evaluasi berbentuk pilihan berganda berupa 3 soal dengan 5 pilihan. Kemudian mencoba untuk mengirimkan keteman dan teman guru laian menjawab. Dari kegiatan ini diberikan waktu untuk berkomunikasi, tim meminta pendapat berupa masukan dari beberapa orang guru mengenai aplikasi yang dibuat oleh temannya namun tidak disarankan hanya megungkapakan kebaikannya karena pertemana, maka kegiatan ini akan menjadi bias.

Dari pertemuan kedua ini peserta sudah bisa menghasilkan aplikasi tes berupa gform yang akan dibagaikan kepada siswa saat pelaksanaan ujian tengah semester. Tugas yang diminta pada pertemuan kedua ini adalah menghasilkan dua buah aplikasi kuis yang. Aplikasi kuis yang pertama dibagikan kepada peserta workshop dan aplikasi kuis yang kdua dibagikan kepada siswa. Tagihan pada kegiatan kedua ini pesert diminta untuk mengirimkan link kuis kepada tim.

Pertemuan ketiga dilakukan pada tanggal 24 Juli, kegiatannya adalah membuat aplikasi google classroom. Terlebih dahulu meminta peserta kegiatan membawa materi pelajaran yang sudah mereka tuangkan dalam bentuk ppt atau pdf, juga meminta peserta membuat evaluasi. Hal ini bertujuan untuk mememudahkan saat memasukkan isi pelajaran pada menu yang dibuat. Instruktur meminta peserta mengikuti insturksi yang dilakukan instruktur, pada asisten instruktur berjalan mengitari peserta jika dapeserta yang tidak bisa maka asisten isntruktur membantu. Dari kegiatan ini terlihat 86\% peserta mampu membuat aplikasi google classroom, dan mampu membagikan kode kelas kepada peserta lainnya. Setelah membuat aplikasi google classroom selesaai dilanjutkan dengan membuat link untuk melakukan pembelajaran dengan cara virtual dengan menggunakan aplikasi google meet.

Hasil dari kegiatan ketiga ini adalah membuat google classroom, kode dari gclassroom diberikan kepada tim dan peserta agar dapat masuk menjadi murid juga diminta untuk kode masuk sebagai guru. Mengapa harus sebgai guru? Hal ini bertujuan agar apabila ada kegiatan penelitian Tindakan kelas ada guru yang menjadi observer dalam kegiatan yang dilakukan teman sejawatnya. Guru merasa sangat senang dengan kegiatan yang dibawakan tim pada pertemuan ketiga. Biasanya hanya menggunakan wa grup, sejak saat ini guru sudah bisa lebih berbuat kreatif dengan menggunakan LMS sederhana yang berasal dari google.

Selesai kegiatan dilakukan wawancara mengenai kegiatan yang telah dilakukan, dari hasil wawancara dapat dikatakan $84 \%$ peserta merasa puas dengan pelaksanaan kegiatan pengabdian masyarakat. Mereka mengatakan banyak mendapatkan ilmu dari kegiatan ini, semula tidak dapat membuat aplikasi share link untuk mengirimkan file dari googledrive. Ada juga yang mengatakan sudah terbiasa menggunakan google diberikan waktu untuk berkomunikasi, tim meminta classroom namun belum terbiasa menggunakan pendapat berupa masukan dari beberapa orang guru mengenai aplikasi yang dibuat oleh temannya namun tidak disarankan hanya megungkapakan kebaikannya karena pertemana, maka kegiatan ini akan menjadi bias. Dari pertemuan kedua ini peserta sudah bisa menghasilkan aplikasi tes berupa gform yang akan dibagaikan kepada siswa saat pelaksanaan ujian tengah semester. Tugas yang diminta pada pertemuan kedua ini adalah menghasilkan dua buah aplikasi kuis yang. Aplikasi kuis yang pertama dibagikan kepada peserta workshop dan aplikasi aplikasi google meet. Bagi guru kegiatan ini memberikan dampak positif sebab tidak hanya penemuhan kebutuhan untuk pjj namun juga menambah ilmu pengetahuan.

Dilain sisi untuk guru-guru yang sudah sepuh kegiatan ini tidak terlalu menarik, menurut mereka lebih baik didatangkan saja siswa keselolah sehingga siswa bisa berinteraksi dengan guru. Pihak sekolah merasa sangat senang dengan kegiatan yang diadakan tim, pihak sekolah merasa mendapat pencerahan baru mengenai aplikasi google dan merasa sangat beruntung bahwa guru-guru disekolah mereka mendapatkan tambahan ilmu.

Dari sisi pihak pelaksana merasa sangat puas atas kinerja guru, guru begitu antusias dalam pembelajaran. Terlihat dari adanya tugas-tugas yang diserahkan guru, walaupun disadari tidak semua guru menyerahkan tugas-tugas rumah dan terlibat dalam diskusi di grup yang dibuat tim.

\section{KESIMPULAN}

Adapun kesimpulan yang dapat diperoleh dari kegiatan pengabdian kepada masyarakat untuk guru SMPN 1 Aikmel sebagai berikut: a) Peserta pelatihan antusias dan bersemangat mengikuti pelatihan penggunaan aplikasi google classroom dapat dilihat dengan keseriusan peserta mengikuti kegiatan praktikum dan mengerjakan tugas rumah. b) Dengan adanya kegiatan pengabdian kepada masyarakat ini peserta pelatihan dapat menggunakan teknologi informasi untuk mendukung kegiatan belajar mengajar selama pandemic. C) Peran aktif peserta beserta hasil yang dicapai selama kegiatan sangat bermanfaat bagi pesrta dan tim. 


\section{UCAPAN TERIMA KASIH}

Terimakasih penulis ucapkan kepada pihak Lembaga Peneliatan dan Pengabdian Masyarakat (LP2M) Universitas Teknologi Mataram yang telah memberikan bantuan dana berupa dana Hibah Pengabdian Masyarakat Sekolah Binaan. Kami juga mengucapkan terimakasih kepada pihak sekolah SMPN 1 Aikmel yang sudah menyediakan tempat untuk kegiatan pengabdian masyarakat ini.

\section{DAFTAR PUSTAKA}

Wijaya, Andri dan Aliyanto, Arif. (2016). Analisis

Kegunaan dan Kemudahan Terhadap Penggunaan Google Apps for Education.Seminar Nasional Inovasi dan Aplikasi Teknologi di Industri (SENIATI) 2016. ISSN: 208- 4218. Malang: Institut Teknologi Nasional.

Surat Edaran Mendikbud Nomor 36962/MPK.A/HK/2020 tertanggal 17 Maret 2020

Subekti, S A., \& Kurniawati A L. (2020). Pelatihan Mendiasain Pembelajaran Daring Menarik Selama Masa Pandemi Covid-19 Dengan Teknologi Pembelajaran Sederhana. Dinamisia: Jurnal Pengabdian Kepada Masyarakat, 4 (4), 588-595.

Awal, R., Wahyuni, S., \& Sari, M. (2019). Pelatihan penggunaan aplikasi Edmodo bagi guru SMP dan SMA Smart Indonesia Pekanbaru. Dinamisia: Jurnal Pengabdian Kepada Masyarakat, 3 (1), 69-75.

Vieira, I., Lopes, A. P., \& Soares, F. (2014). The potential benefits of using videos in higher education. In Proceedings of EDULEARN14 conference (pp. 07500756). IATED Publications

Azarnoosh, M. (2013). Peer assessment in an

EFL context: Attitudes and friendship bias. Language Testing in Asia, 3 (11), 1-10

Izati, R. A. (2018). The influence of friendship bias toward peer assessment in EFL classroom. RETAIN, 6(2), 52-59 